\title{
Investment treaties and national governance in India: Rearrangements, empowerment, and discipline
}

\author{
Josef Ostřanskýl* and Facundo Pérez Aznar ${ }^{2}$ \\ ${ }^{1}$ European University Institute, Villa Paola, Via dei Roccettini 9, 50014 San Domenico di Fiesole (FI), Italy. Email: josef. \\ ostransky@eui.eu and ${ }^{2}$ Facultad de Derecho, Universidad de Buenos Aires, Av. Figueroa Alcorta 2263, CABA, Argentina. \\ Email: facundo.perez@graduateinstitute.ch
}

\begin{abstract}
This article presents selected findings on India relating to the effects of international investment agreements (IIAs) on national governance. Our research used ethnography-inspired methods to explore the often-voiced hypothesis that IIAs induce good governance reforms in their state parties. Our findings demonstrate that the good governance hypothesis is too sweeping and lacks subtlety, but they also bring forward new conceptualizations of the impact of the international investment regime on national governance. Our research shows that governance actors use IIAs selectively in order to advance various agendas and interests. The Indian case study shows that rather than acting like a monolith when reacting to the experience of IIAs, the state is instead a site of struggle between different actors with different motivations, agendas, and interests. In such context, IIAs produce various formal-institutional as well as ideologicaldiscursive effects that have not been captured by the existing literature. First, IIAs lead to the simultaneous practices of internalization through external adjustment and internalization through accommodation. At the same time, these modes of internalization lead to rearrangements by internalization within the public administration. Second, governance actors resort to various narratives about IIAs, which we present in this article. Importantly, the deployments of various narratives about IIAs are context-dependent and are used by governance actors tactically as convenient tools in internal political struggles within the public administration. These findings have important consequences for the design and reform of international investment regulation, should such regulation have ambition, as it does, to promote good governance.
\end{abstract}

Keywords: governance; India; internalization of treaties; international investment law; investment treaties

\section{Introduction}

The literature on international investment law (IIL) often praises the existing international regime for its potential to contribute to the promotion of good governance. In this article, apart from challenging some of the common assumptions about the effects of international investment agreements (IIAs) on

\footnotetext{
*This article is one of the outputs of a larger comparative project funded by the Swiss National Science Foundation (grant: 10001C_150090). We want to thank Zachary Douglas and Shalini Randeria for initiating this project at the Graduate Institute of International and Development Studies, Geneva. We also want to thank the Centre for International Law at the National University of Singapore, for hosting a workshop discussing our article (Jansen Calamita, Ayelet Berman, and Dafina Atanasova) and all the workshop participants for their feedback: Tony Anghie, Prabhash Ranjan, and others, too numerous to be named here. We also want to thank the individuals who have engaged with earlier versions of the article, especially Luna de Araujo, Jonathan Bonnitcha, Anthea Roberts, Florian Hoffmann, the two LJIL anonymous reviewers, and for the research assistance, we thank Debesh Panda. Lastly, we thank the Geneva Center for International Dispute Settlement (CIDS), and RegNet, ANU, for the institutional support. Naturally, for all errors only the authors are to blame. 
national governance, we offer new conceptualizations of the interaction between IIAs and national governance, broadly conceived. Our Indian case study demonstrates how some of the common narratives about the effects of IIAs on national governance in a country from the global South warrant reconsideration.

Conceptually, we first problematize some of the assumptions undergirding the common good governance rationales of IIAs, such as the unitary rational state and public administration. Second, the data generated from our fieldwork show that IIAs have not only formal, legal, and institutional effects. They also produce important ideological and discursive effects. This appreciation allows us to put forward new conceptualizations of modes of internalization of IIAs, such as internalization through external adjustment, and internalization through accommodation, as well as the concept of rearrangement by internalization which encapsulates the changes triggered by the interaction with IIL. Third, we also introduce new conceptualizations of IIAs' functions in the national governance sites based on the analysis of narratives and discourses; such that we show that IIAs may serve as articles of faith, symbolic tokens of economic diplomacy, and unwanted external disciplines. However, they also work as convenient tools in internal power struggles. Importantly, which mode of internalization and which narrative of IIAs the various governance actors resort to is highly context-dependent. Seeming contradictions in governance actors' appreciations of IIAs may be explained when the relational aspects of these contexts are highlighted.

Methodologically, ethnography-inspired qualitative socio-legal methods, as well as interpretative epistemologies have not been widely used to study international investment law and this article demonstrates the usefulness of such approaches.

The article proceeds in two parts. We start by explaining the hypotheses, research questions, methodology, and concepts used in this article, and by situating it within the broader context of empirical and socio-legal literature on IIAs. The next part presents and analyses the impact of IIAs on governance in two sections. First, concerning its formal-institutional incarnation. Here, we analyse how the experiences with IIAs impact on relationships between various governmental agencies, and on policies and processes they facilitate through various modes of internalization. The next section discusses the ideologicaldiscursive effects of IIAs. Here, we analyse how narratives about IIAs have been deployed in various contexts, and how this allows us to view IIAs as empowering as well as disciplining tools in national governance. The conclusion highlights some normative considerations brought about by our findings.

\section{Investigating IIAs' impact on governance: Hypotheses, research questions, methodology, and conceptual framework}

\subsection{Hypotheses and research questions}

The literature on IIAs often suggests that apart from potentially influencing international investment flows and depoliticizing investment disputes, IIAs may have an indirect impact on governance, domestic institutions and decision-making processes. ${ }^{1}$ In theory, IIAs may, through their substantive obligations, induce domestic reform and improve governance processes. ${ }^{2}$ This way, it

\footnotetext{
${ }^{1}$ E.g., R. Dolzer, 'The Impact of International Investment Treaties on Domestic Administrative Law', (2005) 37 NYU Journal of International Law and Politics 953; S. W. Schill, 'International Investment Law and Comparative Public Law - An introduction', in S. W. Schill (ed.), International Investment Law and Comparative Public Law (2010), 1; T. Büthe and H. V. Milner, 'Bilateral Investment Treaties and Foreign Direct Investment: A Political Analysis', in K. P. Sauvant and L. E. Sachs (eds.), The Effect of Treaties on Foreign Direct Investment: Bilateral Investment Treaties, Double Taxation Treaties, and Investment Flows (2009), 171.

${ }^{2}$ For a useful overview of these claims see M. Sattorova, The Impact of Investment Treaty Law on Host States: Enabling Good Governance? (2018), at 1-9; for a typical argument along these lines see, e.g., Schill, supra note 1; S. W. Schill, 'System Building in Investment Treaty Arbitration and Lawmaking', (2011) 12 German Law Journal 1083; R. Echandi, 'What Do Developing Countries Expect from the International Investment Regime?', in J. E. Alvarez et al. (eds.), The Evolving International Investment Regime: Expectations, Realities, Options (2011), 3, at 13. For other international instrument processes and mechanisms influencing domestic legal and administrative transformation see, e.g., Y. Dezalay and B. Garth (eds.), Global Prescriptions: The Production, Exportation, and Importation of a New Legal Orthodoxy (2002); D. Kosař and L. Lixinski,
} 
is argued, the impact of IIAs eventually spills over from the area of governance relating only to foreign investors to the improved governance for all in the host countries (spill-over argument). However, there has been a relative dearth of empirical and socio-legal studies attempting to investigate this claim.

Some quantitative studies have focused on the effect of IIAs on various rule of law and good governance indexes and have found either $\mathrm{no}^{3}$ or negative effect. ${ }^{4}$ Qualitative studies looking more closely at concrete acts and perceptions of governmental officials induced by IIAs and investment treaty arbitration (ITA) have appeared recently. These studies show either little or no impact due to the limited awareness of governmental officials; ${ }^{5}$ alternatively, they evidence some impact through, inter alia, increased influence of the governmental agencies that deal with IIAs agendas over the regulatory process. ${ }^{6}$

The most detailed empirical account on the impact of IIAs on domestic governance as of yet, Sattorova's 2018 monograph based on qualitative case studies of Kazakhstan, Nigeria, Turkey, Ukraine, and Uzbekistan, confirms that the claim of IIAs fostering domestic governance for all is distant from the reality of the studied countries. ${ }^{7}$ It also confirms that IIAs have other effects on domestic governance, which are, however, not of the kind usually propounded by the literature that argues that IIAs have positive spill-over effects. Her work suggests that IIL rather induces the creation of legal enclaves for foreign investors that allow states to better manage and avoid investment claims. ${ }^{8}$

Apart from these studies, limited evidence points to instances of governments not going forward with various regulations when faced with a threat by an investment claim, ${ }^{9}$ as well as instances of governments going ahead with proposed regulations despite investment arbitration threats. ${ }^{10}$

Finally, Ranjan's seminal monograph on India and bilateral investment treaties relies on some of the documentary materials we used in our analysis. However, the questions he aims to answer as well as the perspective he adopts differ markedly from ours, as his work focuses more squarely on the analysis of the evolution of the Indian BIT programme, and doctrinal and policy questions, although always well embedded in an analysis of the historical politico-economic context. Importantly, his investigations into governance effects of IIAs are merely tangential. ${ }^{11}$

We started from the hypothesis that IIAs indeed have an impact on national governance broadly conceived. Our research, hence, enquired into government decision-makers' perceptions

\footnotetext{
'Domestic Judicial Design by International Human Rights Courts', (2015) 109 American Journal of International Law 713 ; P. Bergling, Rule of Law on the International Agenda: International Support to Legal and Judicial Reform in International Administration, Transition and Development Co-operation (2006).

${ }^{3}$ J. P. Sasse, An Economic Analysis of Bilateral Investment Treaties (2011).

${ }^{4} \mathrm{~T}$. Ginsburg, 'International Substitutes for Domestic Institutions: Bilateral Investment Treaties and Governance', (2005) 25 International Review of Law and Economics 107.

${ }^{5}$ M. Sattorova, O. Omiunu and M. Erkan, 'How Do Host States Respond to Investment Treaty Law? Some Empirical Observations', in J. D. Haskell and A. Rasulov (eds.), New Voices and Perspectives in International Economic Law (2020), 133; C. Côté, 'A Chilling Effect? The impact of international investment agreements on national regulatory autonomy in the areas of health, safety and the environment' (2014), PhD thesis submitted at the LSE, London.

${ }^{6} \mathrm{G}$. Van Harten and D. Scott, 'Investment Treaties and the Internal Vetting of Regulatory Proposals: A Case Study from Canada', (2016) 7 Journal of International Dispute Settlement 92.

${ }^{7}$ Sattorova, supra note 2.

${ }^{8}$ Furthermore, she argues that the current remedial mechanisms of IIL fare poorly in inducing any kind of broader domestic legal reforms. Ibid.

${ }^{9} \mathrm{~K}$. Tienhaara, The Expropriation of Environmental Governance (2009), Ch. 8; S. G. Gross, 'Inordinate Chill: BITs, nonNAFTA MITs, and Host-State Regulatory Freedom - An Indonesian Case Study', (2003) 24 Michigan Journal of International Law 893.

${ }^{10}$ Z. Williams, 'Risky Business or Risky Politics: What Explains Investor-State Disputes?', Investment Treaty News, 12 August 2014, available at www.iisd.org/itn/2014/08/12/risky-business-or-risky-politics-what-explains-investor-statedisputes/; P. Ranjan, India and Bilateral Investment Treaties: Refusal, Acceptance, Backlash (2019).

${ }^{11}$ Ranjan, ibid. Moreover, his work adopts an explicitly value-based assessment which differs from the way we incorporate normative evaluations into our analysis.
} 
of and discourses about IIAs and ITA, about formal as well as informal policies, practices, and processes that are put in place as a reaction to IIAs and ITA.

A related hypothesis was that decision-makers' perceptions and actions concerning IIAs are not informed solely by their own assessment of the international investment obligations and the consequences of potential violations, to the extent they are aware of them at all. The public debate over government conduct plays a role in their decisions and their decisions' justifications. This means that the media and civil society are presumably playing an important role in this debate. Equally, the position of a particular official within the broader structure of public administration and the intervening power dynamics within that structure would also affect the actions and their justifications.

Our research confirms some of the findings of the existing literature about the limited impact of IIAs on domestic governance. However, it finds that the actual impact of IIAs is more diverse than what the traditional spill-over argument, as well as the regulatory-chill argument, portray and this impact needs to be further theorized and conceptualized.

\subsection{Methodology 12}

To assess IIAs' impact on governance, quantitative methods such as surveys do not appear well suited. There is a great potential that the data received in surveys will be limited to platitudes and official positions. Our methodological choices have been influenced mostly by anthropological and ethnographic literature on the effect of international law on domestic settings. ${ }^{13}$ Insights from this literature suggest that the use and effects of various international norms within domestic settings have often been ambivalent and cannot be adequately explained by the sole focus either on the international plane or on the state itself. Many other actors and social forces at the national and international levels play a strong role in shaping a state's policies and governance and determine how governance actors selectively react to international law. ${ }^{14}$

Within a wider research project, ${ }^{15}$ we used the method of extended case study, ${ }^{16}$ which relies mostly on open-ended semi-structured interviews with relevant actors, and discourse and content analysis of both official and unofficial documents, such as government memoranda, press releases, media reports, and the like. ${ }^{17}$ We also held a government workshop in Geneva, where representatives from the four selected countries exchanged their views on the countries' experiences with IIAs to make up for the lack of participant observation.

As to the selection of the interview respondents, we started with government officials that have worked in the area of IIL and foreign investment policy. This directed us to the state agencies that deal with either negotiation of investment treaty instruments or with handling the state's defence in investment treaty arbitrations. In India, these are mostly the Ministries of Finance, Commerce, and Foreign Affairs. ${ }^{18}$ These interviews snowballed into the identification of other actors within

\footnotetext{
${ }^{12}$ For more details see J. Ostřanský, 'A Case for Ethnography of International Investment Law', in R. Deplano, G. Gentile and L. Lonardo (eds.), Pluralising International Legal Scholarship: The Promise and Perils of Non-Doctrinal Research Methods (2019), 64 .

${ }^{13}$ See Dezalay and Garth, supra note 2.

${ }^{14}$ S. Randeria, 'The State of Globalization: Legal Plurality, Overlapping Sovereignties and Ambiguous Alliance between Civil Society and the Cunning State in India', (2007) 24 Theory, Culture and Society 1.

${ }^{15}$ The results of the broader project comparing IIAs' governance effects in Argentina, Czech Republic, India, and Mexico are forthcoming in J. Ostřanský and F. Pérez Aznar, National Governance and International Investment Law: Between Constraint and Empowerment (forthcoming).

${ }^{16}$ M. Burawoy, 'The Extended Case Study', (1998) 16 Sociological Theory 4.

${ }^{17}$ The interviews were conducted on-site in India by collaborating researchers Shalini Randeria and Debesh Panda, and in Geneva, to the extent that the relevant respondents were present there (e.g., during the UNCTAD World Investment Forum). Over the course of the project, we conducted interviews with 23 people inside and outside the Indian government.

${ }^{18}$ The institutional structures and divisions of competences proved to be an important factor influencing the ways public administrations dealt with IIAs. Many of these divisions were contingent on historical developments and were rarely a result of
} 
and without the public administration. These were in some cases officials at other 'non-IIL' agencies, judges, and in some cases journalists. More often, however, we were referred to external 'experts' on IIAs and arbitration with whom the government officials held close professional ties and who happened to work with the government on IIL-related matters (such as the preparation of various internal reports and assessments of ITA-related matters). Those external experts were often lawyers from private practice working in the area of international dispute settlement and less commonly law professors.

Although the interviews' content varied depending on the respondent, it generally related to the respondent's experiences with IIL. We discussed the respondents' perceptions of IIL, talked about their professional background, personal experiences, histories, and details of their encounters with IIL. We often asked about the interaction between IIL norms on the one hand, and the local practices, policies, norms, expectations, and perceptions, on the other. All of the interviews were conducted on a non-attributed basis, hence we anonymized them when referencing. ${ }^{19}$

The documentary sources were collected through the desk and limited archival research, through direct contact with the relevant actors, researchers' professional contacts, and by means of official requests for information (RTI) according to applicable laws. ${ }^{20}$ The nature of the documents was variegated and comprised official government documents as well as non-official documentary materials. ${ }^{21}$ The official documents included various reports, memoranda, legislative bills, press releases and the like. In simple terms, we tried to locate any document and text, which would include references to IIAs or ITA.

\subsection{Limitations of and clarifications on the methodology}

It is important to emphasize the limitations of our research, as well as to clarify some of its aspects in order to avoid epistemological charges from the perspective of positivist social sciences. On an epistemological note, in our research, we tried to interpret and understand the practices and perceptions of the observed actors, and what meanings they assign to their daily activities when encountering IIL. Our research was less concerned with the notions of replication, causality, validity and representativeness than it was with the interpretation of the observed processes, practices and utterances. ${ }^{22}$ In this sense, we do not deny that we portray a necessarily partial image - as is, we believe, always the case in social sciences. Yet, we contend that our analysis sheds light on the interaction between IIL and national governance and provides important insights.

Most of the information collected (particularly in the interviews) was retrospective, and as such was not free from 'biases' and potential reactivity. ${ }^{23}$ For our purposes, the reactivity was not

the engagement with the IIAs regime. However, they also changed over time, taking into account the experiences with the regime. More in Ostřanský and Pérez Aznar, supra note 15.

${ }^{19}$ The initials in the references are fictitious to avoid identification. In India, none of the interviewed respondents allowed recording of the interview. Hence, all the data were taken, first, from notes taken by the researcher during the interview, and, second, from notes and observations, added ex post immediately after the interview.

${ }^{20}$ The questions asked in RTI related to the procedures and competences for negotiating and ratifying IIAs; impacts of IIAs on the economy and governance; co-operation among states agencies, Parliament and external experts; budgetary issues related to satisfaction of arbitration awards; relations between the federal and state entities in IIL-related matters; information on historical and ongoing IIAs disputes, etc. They were addressed (or transferred) to Ministries of Commerce, Finance, Foreign Affairs, Law and Justice, Communications, Coal, and Power.

${ }^{21} \mathrm{We}$ use the notion of 'official' interchangeably with 'governmental' in common parlance to connote that an individual, institution or document belongs to or originates in the official state apparatuses.

${ }^{22}$ J. Flood, 'Socio-Legal Ethnography', in R. Banakar and M. Travers (eds.), Theory and Method in Socio-Legal Research (2005), 33, at 34 .

${ }^{23}$ By reactivity, we mean the situation in which the respondent changes their cognitive process as a result of the verbalization of a question. In other words, the researcher's question may trigger a thought process which the respondent has not had and thought about when dealing with the object of the question. L. McKechnie, 'Reactivity', in L. M. Given (ed.), The SAGE Encyclopedia of Qualitative Research Methods (2008), 729. 
viewed as an issue. It does not matter whether the justification for the respondent's conduct is added ex-post by virtue of being asked a specific question, as the ex-post justification still provides us with data about the decision-making. More importantly, however, potential 'biases' in responses were not viewed as problematic for our study focused not only on formal and informal processes and practices but equally on the decision-makers' perceptions and on the official and unofficial narratives and discourses about IIL. Potential dissonances and contradictions between perceptions and narratives, on the one hand, and the actual conduct, practice and policy, on the other, were themselves taken as data and therefore they have a productive use.

Similarly, as with the potential 'biases', we had to acknowledge that the typical positivist dividing line between the researcher (outside) and the field (inside) does not find its place in our framework, as the researcher is simultaneously positioned inside and outside. ${ }^{24}$

As our methods and theoretical outlook were contextual, dynamic and reflexive, we intentionally did not attempt to 'silence' certain information, which may have initially appeared irrelevant. Apart from our main hypotheses, we did not intend to limit our enquiry by upfront definitions, such as a definition of good governance. Nevertheless, we established at the outset themes and directions in which we inductively moved our research and modified them as we went forward. The research questions and hypotheses were, in a sense, only guidance to influence our thinking about the research topic. ${ }^{25}$ They were not there to make us "enslaved by a theoretical straitjacket'. ${ }^{26}$

The next section introduces the conceptual framework we used to make sense of the collected data, and which allowed us to shed light on the material and discursive reality of the interaction between IIL and national governance in India.

\subsection{Understanding IIAs' impact on governance: A conceptual framework}

\subsubsection{IIL's formal-institutional and ideological-discursive effects}

The majority of the literature on the spill-over effects focuses on formal, legal, and institutional effects: changes in laws, regulations, competences, and legal processes - we pile these effects under the heading formal-institutional. From this perspective, one may assume, for instance, that when a disagreement between various government agencies as to the implementation of IIAs does not have a tangible result in law, policy, procedural and institutional change, there are no significant consequences for governance. This type of perspective, however, understands governance effects in a very narrow way. Other kinds of governance effects that IIL may potentially have are therefore not captured by this perspective. To cast the net of our analysis wider, we must think about IIL in different ways.

While we acknowledge the effects we describe as formal-institutional, there are also ideological, discursive, and interpellation effects of IIL. ${ }^{27}$ If we understand IIL as an ideological and discursive mechanism - i.e., shaping actors' ideas as to what is right and wrong, legitimate and illegitimate, possible and impossible, normatively superior, etc. ${ }^{28}$ - and, drawing on Foucault, as a mechanism of interpellation - i.e., a mechanism which, through various processes and practices, trains actors to adopt a certain style of comportment, self-expression, and being-in-the-world ${ }^{29}$ - we can

\footnotetext{
${ }^{24} \mathrm{By}$ 'inside', we essentially mean being 'experts' on international investment law, in the sense of understanding the technical language, debates and stakes in the field. None of the authors have ever worked with or for the Indian government in any capacity. More detail in Ostřanský, supra note 12.

${ }^{25}$ Flood, supra note 22 , at 34.

${ }^{26}$ Ibid., at 35 .

${ }^{27}$ On various theories of law's effectivities, especially the ideological and interpellation theories, see A. Rasulov, 'The Discipline of International Economic Law at a Crossroads', in J. D. Haskell and A. Rasulov (eds.), New Voices and New Perspectives in International Economic Law (2020), 1.

${ }^{28}$ Ibid., at 20.

${ }^{29}$ Ibid., at 21 .
} 
appreciate IIL's effects beyond those that translate into black-letter law and policy. Understood this way, IIL frames the actors' normative ideals as well as their ways of 'doing governance'.

There are all kinds of effects (governance effectivities) of IIL, and to close up those that do not translate into formal reforms as creating no consequences for governance is a contention we want to oppose. Our perspective 'seeks to discern and decipher the myriad of ways in which the [IIL] operates in everyday life of states, societies, and people across the globe', ${ }^{30}$ and thus reframe governance in light of concrete circumstances.

\subsubsection{Governance effects and governance sites}

Understanding IIL not only as a formal-institutional but also as an ideological, discursive, and interpellation mechanism has consequence for the research design and conceptual framework. In our research, we aimed at documenting, analysing and explaining how IIL interacts with governance sites in the studied countries. This presupposes some notions of the sites and layers of social praxis affected by IIL.

We initiated our research with a presumption that these sites are multiple and not limited to the governmental institutions but are also found in the media and academic discourse, NGOs' activities, business, investors, and international organizations' activities. At these sites, the 'international', represented by IIL and its accompanying globalizing discourses, is transformed, filtered, and mixed with local and national meanings. Our research is informed by the notion of multi-sitedness, ${ }^{31}$ as it looks at how abstract and large-scale systems, norms, and discourses are received at and interact with various local sites.

The idea that governance is a set of processes, practices as well as their effects cannot lead immediately to the conclusion that they exist only within the apparatus and institutional structure of governments. ${ }^{32}$ Our project design started with a focus on the official governmental apparatus and the media discourse about IIAs. As the research progressed, we received indicia which would lead us to pursue paths to other sites where governance may obtain, such as law firms, investors, and international organizations. When faced with a dilemma as to the extent to which we should follow these indicia, we stayed at the level of official sites and a limited investigation into the interaction between official sites, on the one hand, and law firms, media and NGOs, on the other. ${ }^{33}$ Due to space limitations, in this article, our focus is limited to the official, state governance sites. ${ }^{34}$

\subsubsection{Tracing the impact of an 'IIL-argument'}

When analysing how IIL influences the more formal aspects of national governance, such as laws, regulation and governmental policies, we tried to trace the route of what we called 'an IIL-argument'. An IIL-argument is essentially a text which travels through various agencies and sites and is mediated, transformed, and repurposed through the interaction with various actors. ${ }^{35}$ For instance, an IIL-argument may originate as a treaty which finds its way into the legislative process

\footnotetext{
${ }^{30}$ F. Hoffmann, 'Facing South: On the Significance of an/other Modernity in Comparative Constitutional Law', in P. Dann, M. Riegner and M. Bönnermann (eds.), The Global South and Comparative Constitutional Law (2020), 41.

${ }^{31}$ See, e.g., G. E. Marcus, 'Multi-sited Ethnography: Five or Six Things I Know About It Now', in Problems and Possibilities in Multi-sited Ethnography Workshop, 27-28 June 2005, University of Sussex.

${ }^{32}$ M. R. Trouillot, 'The Anthropology of the State in the Age of Globalization: Close Encounters of the Deceptive Kind', (2001) 42 Current Anthropology 125, at 131.

${ }^{33}$ The reasons were connected to the positioning of our research project within the larger disciplinary debate about the effects of IIL, as well as to the funding of our research project.

${ }^{34}$ Treatment of the wider scope of questions with an added comparative angle will be published in Ostřanský and Pérez Aznar, supra note 15.

${ }^{35} \mathrm{On}$ the notion of mobilization of texts and documents in micro-sociology or ethnography see, e.g., T. Scheffer, 'Courses of Mobilisation: Writing Systematic Micro-Histories of Legal Discourse', in R. Banakar and M. Travers (eds.), Theory and Method in Socio-Legal Research (2005), 75.
} 
based on an experience of ITA, which relays information about the potential consequences of the treaty violation. If such information is retained within the administration, the treaty may find its way into a governmental memorandum in support of or against a legislative bill; or yet, may form a basis for the establishment of a new policy or practice of reviewing legislative proposals. Another example is a way an investment award may enter the public discourse. Government officials may instrumentally use the result of arbitration in a campaign against the opposition. A lost arbitration, a negative occurrence for the government at first sight, may thus turn into a tactical tool against political opponents.

By focusing on how certain textual information travels, we problematize the usual assumptions found in IIL doctrinal literature about normatively positive or negative effects. ${ }^{36}$ This perspective allows seeing beyond the formal manifestations of governance that are at the heart of most discussions about the impact of IIL on good governance. It allows us to see how even actors without formal decision-making power, and even outside the public administration altogether, may influence governance with the aid of IIL.

\subsubsection{Narrativization of IIL: Conflicts and contradictions}

In this article, we identify various narratives which government officials tell themselves and their audiences about IIL and their changes over time. This analysis operates with perceptions, opinions, and judgements that governance actors voice. These perceptions and judgements give us insights about what these actors value, how they justify their and others' actions within the broader sphere of official governance, and how they try to make sense of the Indian experiences with IIL - what stories they tell about IIL in India. This is what we mean by narratives.

Narratives are therefore manifestations of ideological and normative evaluations of a particular phenomenon and are at the same time functions of the context in which they operate. They are thus necessarily coloured by the actor's positioning, agendas and interests.

This approach allows us, first, to construe the governance actors' ideational worlds based on the actors' experiences with IIL and their interactions with it. Second, extracting the general from the particular, while bearing in mind the relevant contexts, allows revealing and understanding conflicts and contradictions that are not necessarily evident if the contexts are not taken into account, and when the research design filters out contradictory or partial utterances as instances of ad hoc anecdotes or irrelevant data.

Our research reveals that various actors often hold contradictory views and utter contradictory statements about IIL depending on the context. These contradictions may be unwitting but are often also tactical. By this, we mean that different actors may at times resort to different appreciations, portraits and narratives of and about IIL in order to put forward various agendas or simply to manoeuvre through a particular situation. ${ }^{37}$ For the very same actors, IIL thus may be viewed as a constraining force externally imposed in one context, while in another context it may be perceived as a useful tool in various struggles.

While focusing on narratives, contradictions and contexts, we are getting a fuller picture as to the interaction between national governance and IIL. This perspective brings into relief novel and hitherto unexplored realities of IIL and reveal a side of IIL that is generally obscured in the conventional accounts. In other words, this approach allows us to see how IIAs contribute to mediating and negotiating different power relations within the national governance sphere. This way, IIAs influence the governance structures, hierarchies, relations, and processes through different modes of internalization, which this type of analysis allows us to reveal and further conceptualize.

\footnotetext{
${ }^{36}$ See Dolzer, supra note 1; Schill, supra note 1; Schill, supra note 2; Echandi, supra note 2.

${ }^{37}$ We wish to thank Luna de Araujo for bringing our attention to the concept of 'manoeuvring'. See L. de Araujo, "'I am not an Accountant, but I Have to Control Everything”: The Embeddedness of Chronic Healthcare in Paperwork', (forthcoming) (on file with authors).
} 


\section{IIAs' impact on governance in India}

In this part, we apply our conceptual framework to analyse the IIL's impact on national governance in India. First, we briefly summarize important historical events that shaped approaches to IIL in India. This allows us to better contextualize the findings presented afterwards. Second, we present the formal-institutional effects of IIL, which in India we identified mostly concerning its treaty programme and regarding the relationships between various government agencies and institutions. We also discuss the limited instances of dispute prevention policies and practices. Thirdly, we present IIL's ideological-discursive effects. These relate chiefly to the oftencontradictory narratives about IIAs, their purposes and perceived effects.

\subsection{Historical milestones in the Indian IIL experience}

\subsubsection{First period of negotiations of IIAs}

India started to negotiate IIAs in the 1990s. ${ }^{38}$ In 1991, India initiated a process of liberalization of its economy, putting emphasis both on foreign trade and foreign direct investment. ${ }^{39}$ In 1994 , India signed its first bilateral investment treaty (BIT) with the United Kingdom. ${ }^{40}$ From the cables received from the Foreign \& Commonwealth Office of the United Kingdom concerning the preparatory works of the India-UK BIT, it appears that the first round of negotiations was held in late January 1994 in London and the second took place in Delhi on February $1994 .{ }^{41}$ Meetings were held not only with agents of both countries; senior British business representatives were also part of the High Commissioner's dinner. ${ }^{42}$ According to a cable, these British business representatives were willing to talk about 'what they look for before making long-term investment decisions in terms of liberalization measures and non-discriminatory treatment'. ${ }^{43}$ The British considered that the text had reflected an agreement which 'enshrines widely accepted principles and standards important for encouragement of foreign investment' and that the agreement also 'demonstrates commitment of both Governments to create climate of confidence in which investors can operate and take long-term business initiatives' ${ }^{44}$

From 1994 to 2013, India signed a total of 83 BITs and some free trade agreements (FTAs) with investment chapters that included investor-state arbitration. ${ }^{45}$ The peak in the signature of BITs was in 1998 with ten BITs signed. However, the number of BITs concluded annually was decreasing until reaching three BITs per year between 2009 and 2011 with a further significant slowdown post-2011. From those 83 BITs, nine have never entered into force. Indian treaties usually followed the orthodox European BITs in their structure, content and scope. ${ }^{46}$ As regards the pronounced reasons for concluding BITs, the attraction and protection of foreign investment were predominant.

\footnotetext{
${ }^{38}$ See UNCTAD, Investment Policy Hub, available at investmentpolicy.unctad.org/international-investment-agreements. For a detailed historical overview of the Indian engagement with the IIL regime see Ranjan, supra note 10.

${ }^{39}$ Department of Economic Affairs, Ministry of Finance, 'Transforming the International Investment Agreement Regime: The Indian Experience', UNCTAD Expert Meeting, 25 February 2015 (on file with authors); interview with R. N., international law academic, occasional advisor for the government (2015); interview with O. I., international law academic, former member of the Law Commission of India (2015).

${ }^{40}$ India usually refers to bilateral investment treaties as bilateral investment protection and promotion agreements, BIPAs.

${ }^{41}$ Cable dated 25 January 1994 (on file with authors).

${ }^{42}$ Cable dated 15 February 1994 (on file with authors).

${ }^{43}$ Ibid.

${ }^{44}$ Ibid.

${ }^{45} 2005$ India-Singapore Comprehensive Economic Cooperation Agreement (CECA); 2009 India-South Korea Comprehensive Economic Partnership Agreement; 2011 Japan-India Economic Partnership Agreement; 2011 IndiaMalaysia FTA; 2014 ASEAN-India Investment Agreement.

${ }^{46}$ The 1993 Model was based on the 1967 OECD Draft Convention on the Protection of Foreign Property, see Ministry of Finance, 'Transforming the International Investment Agreement Regime', supra note 39, at 3.
} 
The BITs concluded between 1994 and 2012 appear to have been concluded without regard for the legal and policy ramifications and have been considered 'benign instruments'. ${ }^{47}$ They were viewed as agreements restricted to matters where 'none disagreed'. ${ }^{48}$ 'The idea was to get foreign money. ${ }^{\text {'9 }}$

When queried as to the purpose of signing these BITs, one government official stated that some BITs were signed due to pressure from other countries who were desirous of taking advantage of the dispute resolution clause. ${ }^{50}$ However, this opinion might have benefited from hindsight. The Ministry of Finance stated that the negotiation of IIAs has aimed 'at providing foreign investors with a level of legal assurance regarding the protection of their investments' ${ }^{51}$ Some respondents privy to treaty negotiations in this period intimated that the treaty negotiations were not mere occasions of signing boiler-plate instruments, and trade-offs on various issues were being discussed even in the earlier periods. ${ }^{52}$

\subsubsection{First wave of investment claims}

In 2003, India started receiving investment claims. The first nine treaty cases against India were initiated between 2003 and 2004 under different IIAs and all related to the Dabhol combined cycle power plant project in the Indian state of Maharashtra. ${ }^{53}$ All of these claims were eventually settled before reaching the arbitration phase. The following case against India was White Industries $\mathrm{v}$. India, registered in $2010 .^{54}$

Interviewed respondents questioned whether the Dabhol cases would be an appropriate starting point for analysing India's greater interaction with ITA. ${ }^{55}$ One respondent noted that some lessons were learned, however, and that after the Dabhol settlement (allegedly close to US $\$ 1$ billion), there had been some changes in India's IIAs (e.g., changes in the expropriation provision in the India-Singapore CECA $)^{56}$ and it had become clear to the government that it would have not been able to defend itself in the arbitration, so it had preferred to reach a settlement. ${ }^{57}$

Compared to a relative silence in the public discussion on the topic of IIAs until $2010,{ }^{58}$ discussions in the media, as well as interactions with other government institutions, have become much more frequent thereafter, as a result of the White Industries arbitration.

\footnotetext{
${ }^{47}$ Interview with O. I. (2015).

${ }^{48}$ Ibid.

${ }^{49}$ Interview with S. Y., private practitioner involved in investment disputes as counsel for India (2014); interview with Z. F., private practitioner, advising Ministry of Commerce on BITs (2013); interview with G. V., former official at the Ministry of Foreign Affairs, negotiator of BITs (2013).

${ }^{50}$ Interview with E. N., official Ministry of Foreign Affairs (2015).

${ }^{51}$ Parliament of India, Rajya Sabha (Council of States), Unstarred Question NO-2615, 20 April 2010.

${ }^{52} \mathrm{G}$. V. mentions the investment definition in the 1997 Sri Lanka-India BIT (looser definition to take cognizance of the Tamil issue) and the territory definition in the 1998 Turkey-India (concerns about the case of Northern Cyprus).

${ }^{53}$ These cases are Bechtel v. India; Standard Chartered Bank v. India; Offshore Power v. India; Erste Bank v. India; Credit Suisse v. India; Credit Lyonnais v. India; BNP Paribas v. India; ANZEF v. India; ABN Amro v. India.

${ }^{54}$ White Industries Australia Limited v. The Republic of India, UNCITRAL, Final Award, 30 November 2011.

${ }^{55}$ Interview with A. E., private practitioner involved in investment disputes as counsel for India (2016).

${ }^{56}$ Analysing the IIAs signed by both India and Singapore immediately prior and after the India-Singapore CECA, Art. 6.5 of CECA includes a provision on expropriation relating to land, which shall be governed by domestic legislation. Such provision is not commonly found in the provisions on expropriation in IIAs of the two states.

${ }^{57}$ Interview with R. N. (2015). Interestingly, as late as in 2011, an internal paper by the Department of Industrial Policy and Promotion, Ministry of Commerce, acknowledged that it did not know the amount for which the cases had been settled ('International Investment Agreements between India and Other Countries', 16, on file with authors). One respondent mentioned that India has a 'conciliatory culture'. As opposed to the 'Western, more "process-based culture", the Indian culture is more "relationship-based". Interview with R. A., private practitioner counselling India on IIA-matters (2015). Another respondent quipped that 'if it were politically expedient, the government would settle all disputes'. Interview with A. E. (2016).

${ }^{58}$ E.g., 'Offshore banks launch arbitration for recovery of claims in Dabhol', Financial Express, 10 December 2004, available at www.financialexpress.com/archive/offshorebankslauncharbitrationforrecoveryofclaimsindabhol/122438/; C. P. Chandrasekhar and J. Ghosh, 'Dangers of bilateral investment treaties', Hindu Business Line, 18 April 2006, available at www. thehindubusinessline.com/todays-paper/tp-opinion/dangers-of-bilateral-investment-treaties/article1731107.ece.
} 


\subsubsection{Shift after the White Industries award}

A significant change as regards IIAs in India came in 2010 with the initiation of the White Industries v. India case, which was decided in favour of the investor in $2011 .{ }^{59}$ The claim arose out of judicial delays that left the claimant unable to enforce an International Chamber of Commerce award concerning a contractual dispute with Coal India, a state-owned mining entity, for over nine years. According to one respondent, the conscious cognisance of the IIAs' potential came only after the loss in White Industries. ${ }^{60}$ India's Law Commission Report on the 2015 Draft Model BIT states that IIAs 'did not attract much attention' prior to $2010 .{ }^{61}$

After the White Industries award, important government agencies came to believe that the main problem was loosely worded BITs. The Minister of Commerce mentioned that in light of the lost arbitration, the government would review the Model BIT. ${ }^{62}$ The reaction to the first case decided against the country was an immediate attempt to change, amend, and reformulate some of the provisions which had been crucial in the White Industries dispute. This reaction was concurrent with a review of the bulk of the country's existing IIAs and a moratorium on signing new ones pending the review.

Following White Industries, there have been numerous investment cases brought against India involving measures taken by all three government branches. There have been claims involving measures taken by the executive power and its agencies, ${ }^{63}$ claims involving measures taken by the legislative power, ${ }^{64}$ as well as claims involving measures taken by the judiciary. ${ }^{65}$ There have also been claims involving measures adopted by Indian states and subdivisions. ${ }^{66}$

\subsection{Formal-institutional impacts of IIL: Law, policy, and inter-agency relationships}

In India, the formal-institutional effects of IIL we demonstrate are in relation to the Indian investment treaty programme, the relationships between various state agencies, and limited dispute prevention processes and mechanisms.

\subsubsection{The Indian Investment Treaty Programme: IIAs review, moratorium, and the New Model BIT}

In March 2013, in response to a Parliamentary question, the Minister of Finance replied that given the recent developments, including the adverse arbitration award in White Industries and other dispute notices against India, the government had decided to put all Bilateral Investment Promotion and Protection Agreement (BIPA) negotiations on hold. ${ }^{67}$ In May 2013, the Ministry of Finance, the traditional promoter of IIAs, announced that the government had decided to review the text of the Model BIT, which would be carried out by the Standing

\footnotetext{
${ }^{59}$ White Industries $v$. India, supra note 54.

${ }^{60}$ Interview with H. S., high-level official Ministry of Finance (2014).

${ }^{61}$ The Law Commission of India, Analysis of the 2015 Draft Model Indian Bilateral Investment Treaty, August 2015, Report No. 260, available at lawcommissionofindia.nic.in/reports/Report260.pdf, para. 1(4).

${ }^{62}$ Minister of Commerce and Industry asked by an MP Raghavan Shri MK (Lok Sabha), 6 May 2013.

${ }^{63}$ For a legal analysis of the Indian investment disputes see Ranjan, supra note 10, Ch. 6., Maxim Naumchenko, Andrey Poluektov and Tenoch Holdings Limited v. The Republic of India, PCA Case No. 2013-23; CC/Devas (Mauritius) Ltd., Devas Employees Mauritius Private Limited, and Telcom Devas Mauritius Limited v. Republic of India, PCA Case No. 2013-09, Award on Jurisdiction and Merits, 25 July 2016; Deutsche Telekom v. India, PCA Case No. 2014-10.

${ }^{64}$ Vodafone International Holdings BV v. Government of India, PCA Case No. 2016-35, also dealing with taxation.

${ }^{65}$ White Industries v. India, supra note 54; Khaitan Holdings Mauritius Limited v. India, PCA Case No. 2018-50; Strategic Infrasol Foodstuff LLC and The Joint Venture of Thakur Family Trust, UAE with Ace Hospitality Management DMCC, UAE v. India, UNCITRAL; Astro All Asia Networks and South Asia Entertainment Holdings Limited v. India, PCA Case No. 2016-24/25.

${ }^{66}$ Bechtel Enterprises Holdings, Inc. and GE Structured Finance (GESF) v. The Government of India, UNCITRAL; Ras-AIKhaimah Investment Authority v. India, UNCITRAL.

${ }^{67}$ Parliament of India, Lok Sabha (House of the People), Unstarred Question NO: 4322, 22 March 2013.
} 
Committee of Secretaries and a Working Group. ${ }^{68}$ Almost simultaneously, without much engagement with other stakeholders, the government started a policy of terminating its IIAs. In 2013, it started sending notes of termination to its IIAs counterparts and by 2019, it had terminated 67 out of 84 BITs. ${ }^{69}$

In December 2015, India adopted its new Model BIT as a response to the increasing number of investment claims. Thereafter, it pursued treaty negotiations based on its new template with multiple states. In October 2016, representatives from Brazil and India announced that they had recently initialled a BIT (the treaty follows to a large extent the Brazilian model without investor-state arbitration with elements of the new Indian model; it was signed in January 2020).$^{70}$ In 2018, India signed a new BIT with Belarus, ${ }^{71}$ which closely follows the provisions of India's model BIT, as does the agreement concluded with Taiwan, ${ }^{72}$ the joint interpretive note with Colombia, clarifying the BIT concluded in 2009, ${ }^{73}$ and other joint interpretative notes, which all aim at aligning the existing IIAs with the content of the new Model BIT. ${ }^{74}$

\subsubsection{Relationships between government agencies}

In India, the Department of Economic Affairs (DEA) at the Ministry of Finance negotiates and concludes stand-alone BITs, while investment chapters in broader FTAs are negotiated by the Department of Industrial Policy and Promotion (DIPP) at the Ministry of Commerce. ${ }^{75}$ The IIAs do not require approval by Parliament to be ratified. Finance and Commerce are assisted in IIAs negotiations by the Law \& Treaties (L\&T) Division at the Ministry of Foreign Affairs.

A former senior official at the L\&T intimated that the Indian public administration is based on the Russian model - Indian civil servants have a very broad mandate to negotiate apart from a general policy brief from the Minister, which translates into great flexibility, independence and power. ${ }^{76}$

In the following, we analyse how the IIAs experience has impacted on the relations between various government agencies, starting with the federal government agencies and then moving to the relations between the federal government and individual states.

3.2.2.1 Federal agencies. IIAs have had an impact on the relations between central governmental agencies. The investment claims against India have very often reflected a lack of co-ordination and

\footnotetext{
${ }^{68}$ Parliament of India, Lok Sabha (House of the People), Unstarred Question NO: 6001, 3 May 2013.

${ }^{69}$ See UNCTAD, Investment Policy Hub, 'India: Bilateral Investment Treaties', supra note 38; A. Ross, 'India's termination of BITs to begin', Global Arbitration Review, 23 March 2017, available at globalarbitrationreview.com/article/1138510/indiastermination-of-bits-to-begin.

${ }^{70}$ See Ministry of Foreign Affairs, 'India-Brazil Joint Statement during the visit of President of Brazil to India', 17 October 2016, available at www.mea.gov.in/bilateral-documents.htm?dtl/27499/IndiaBrazil+Joint+Statement+during +the +visit +of + President+of+Brazil+to+India; M. D. Brauch, 'The Best of Two Worlds: The Brazil-India Investment Cooperation and Facilitation Treaty', Investment Treaty News, 10 March 2020, available at iisd.org/itn/2020/03/10/the-best-of-twoworlds-the-brazil-india-investment-cooperation-and-facilitation-treaty-martin-dietrich-brauch/?utm_source=International $+\mathrm{I}$ nstitute+for+Sustainable+Development + Newsletters+Network\&utm_campaign=5b16a0df51-EMAIL_CAMPAIGN_2018_ 04_24_COPY_01\&utm_medium=email\&utm_term=0_3dd24ff452-5b16a0df51-225939093.

${ }^{71}$ The agreement with Belarus is available at mea.gov.in/Portal/LegalTreatiesDoc/BL18B3432.pdf.

${ }^{72}$ The agreement with Taiwan is available at dea.gov.in/sites/default/files/BIA\%20between\%20ITA\%20and\%20TECC.pdf.

${ }^{73}$ The agreement with Colombia is available at mea.gov.in/Portal/LegalTreatiesDoc/CO18B3453.pdf.

${ }^{74}$ See Government of India, Ministry of Finance, Department of Economic Affairs, Office Memorandum, 'Issuing Joint Interpretative Statements for Indian Bilateral Investment Treaties - regarding', F. No. 26/07/2013-IC, 8 February 2016; interview with A. Y., high-level official Ministry of Finance (2015); Arts. 2(4), 6(3) and 11(iii) of the Model BIT adopted in December 2015; 'Joint Interpretative Notes on the Agreement between the Government of the Republic of India and the Government of the People's Republic of Bangladesh for the Promotion and Protection of Investments', available at dea. gov.in/sites/default/files/Signed\%20Copy\%20of\%20JIN.pdf.

${ }^{75}$ E.g., DIPP, 'International Investment Agreement between India and Other Countries', supra note 57.

${ }^{76}$ Interview with O. S., former senior official of L\&T at the Ministry of Foreign Affairs (2013).
} 
communication among the agencies before and during disputes. ${ }^{77}$ Some respondents noted that it is not clear which agency should deal with the defence of the state. ${ }^{78}$

Inter-institutional tensions and rearrangements can be viewed as stemming from an unclear division of competences as to which agency/agencies should deal with the agenda. The Ministries of Finance and Commerce have often been viewed as two competing agencies. These tensions have been expressed in competing policy proposals. The Ministry of Commerce has favoured regional trade agreements and wanted to terminate BITs, ${ }^{79}$ a policy which the Ministry of Finance has historically opposed ${ }^{80}$ Furthermore, tensions between DIPP and DEA were observed regarding the views on the future of IIAs, the content of treaty provisions, ${ }^{81}$ on how to deal with disputes initiated by investors, ${ }^{82}$ but also on the competence to negotiate IIAs. ${ }^{83}$ Some respondents qualified the tensions as 'great turf issues', ${ }^{84}$ while others merely stated that the agencies are 'competing structures' ${ }^{85}$

A senior journalist noted that the origins of:

[t]urf wars are in the tension between trade and revenue. The Finance Ministry typically thinks that FTAs involve loss of revenue to the exchequer whereas the BITs/BIPAs are ostensibly revenue neutral. When this conflict becomes excessive, the [Prime Minister's Office] typically steps in as an arbiter. ${ }^{86}$

Concerning the Model BIT, IIAs' review, and moratorium, some acknowledged too many different perspectives within the government. ${ }^{87}$ The Law Commission of India took on the review of the Model Draft BIT on its own motion, without waiting for the government's request (apparently on the initiative of its chairman A. P. Shah) ${ }^{88}$ The Law Commission felt the need that the Draft Model text needs to be substituted with 'a balanced negotiating text' since 'no country in their right mind would sign it'. ${ }^{89}$ The Law Commission felt that the government needed a 'course-correction'. ${ }^{90}$ This is an indication not only of different perspectives between a body composed mostly of jurists and more political and bureaucratic agencies. It also shows that legal expertise shapes political preferences with the aim of influencing policy in particular ways.

\footnotetext{
${ }^{77}$ It has been noted that there is no uniform practice on handling the disputes. In theory, the notices should be sent to DEA, but often arrive at different agencies. After DEA receives them, it convenes an Inter-Ministerial Group - IMG (Secretary of Economic Relations, MEA, Secretary DEA, Law Secretary) chaired by the Secretary of the Ministry/Department concerned, i.e., the author of the disputed measure. Parliamentary question to Minister of Finance by MP Ajay Kumar (Lok Sabha), 22 March 2013, List of Questions for Oral Answers. IMG decides on the counsel and arbitrator, the internal policy is not to choose firms that have previously represented investors, and there is an internal list of potential arbitrators. Interview with E. N. (2015). The High-Level Committee on Arbitration also recommended in its 2017 report to create a unified procedure and a nodal agency to handle the defence.

${ }^{78}$ Interview with E. N. (2015); interview with A. Y. (2015); interview with O. E., private practitioner and external government consultant (2015).

${ }^{79} \mathrm{D}$. Seth, 'Department of industrial policy \& promotion pitches for sunset clause to terminate all BIPPAs', Economic Times, 18 July 2014, available at economictimes.indiatimes.com/news/economy/foreign-trade/department-of-industrial-policypromotion-pitches-for-sunset-clause-to-terminate-all-bippas/articleshow/38577444.cms

${ }^{80}$ Interview with Z. F. (2013).

${ }^{81}$ E.g., whether to leave out taxation. Interview with H. S. (2014).

${ }^{82}$ Arun Jaitley's Letter to PMO on Vodafone Arbitration dated 26 May 2017 in S. Chaturvedi, 'Modi's Minimum Raj: Jaitley Forwarded Anonymous Note to Flag Key Matter to PMO', The Wire, 5 April 2018, available at thewire.in/government/modisminimum-raj-jaitley-sent-anonymous-note-to-flag-key-matter-to-pmo.

${ }^{83}$ Interview with R. N. (2015).

${ }^{84}$ Interview with O. E. (2015).

${ }^{85}$ Interview with H. S. (2014).

${ }^{86}$ Interview with C. V., senior economic and political analyst at the Business Standard (2013).

${ }^{87}$ Interview with O. I. (2015).

${ }^{88}$ Interview with J. H., senior member of Indian judiciary (2015); also see the Law Commission Report, supra note 61, at para. 1(19).

${ }^{89}$ Interview with J. H. (2015); the Law Commission Report, supra note 61, at para. 1(12).

${ }^{90}$ Interview with J. H. (2015).
} 
It had been expected that the government would accept the Law Commission's recommendations only in part. ${ }^{91}$ This indeed turned out to happen, as is clear from a comparison between the draft and the final Model text adopted in December 2015.

After the elections in May 2014, internal disputes between the ministries started getting ironed out and the Ministry of Commerce adopted a more conciliatory tone because of which the Ministry of Finance, which has been the traditional promoter of BITs, got a stronger position. ${ }^{92}$ Despite that, however, the fate of the older Indian IIAs became termination and renegotiation based on the new model.

It was also noted that the national investment treaty policy is largely personality-driven; there is 'little institutional memory and expertise.$^{93}$ A perceived lack of domain expertise among government officials, a lack of communication and co-operation among ministries, and a lack of continuity in the civil service due to the rapid rotation of officials are contributing to the uncharitable portrayals of the Indian experience. ${ }^{94}$ Interviewed respondents noted, in particular, the lack of expertise inside the government when the disputes arose; 'they had nobody to turn to domestically for advice, lawyers abroad charge too much and it becomes difficult to justify it internally' ${ }^{95}$

Some respondents claimed that the L\&T, especially, lacks the necessary in-house expertise, and due to the competition issues with other governmental agencies, it was actively getting in the way of appointing competent legal counsel. ${ }^{96}$ At the same time, interviews with officials from L\&T did not suggest that the officials would significantly lack understanding and knowledge of IIL.

3.2.2.2 Federation-state relationships. IIL has impacted also the relations between the central government and individual states. As noted above, there have been cases involving measures by Indian subdivisions and individual states. ${ }^{97}$ Investment disputes of this type sometimes reflect political differences between different political levels. ${ }^{98}$ It was even argued that sometimes local governments decide to act arbitrarily, as they know it will be the central government which will have to deal with the fallout. ${ }^{99}$

The central government is aware of the issue of attribution of state governments' conduct to India and its potential consequences for future investment disputes. Article 2(4)(i) of the Model BIT states that the treaty 'shall not apply to any measure by a local government', meaning urban local body, municipal corporation or village level government, or an enterprise owned or controlled by any of the previous bodies. ${ }^{100}$ Conduct of sub-national governments, i.e., state governments, on the other hand, is covered by the Model BIT. This New Model BIT language is, nevertheless, absent from the vast majority of the stock of India's IIAs. Under the older treaties, it is the general rules on state responsibility that apply and those potentially cover the conduct of a larger spectrum of actors than under the Model BIT.

At the same time, however, the central government seems willing to use the IIA-argument internally to responsibilize individual states. In parliamentary questions to the Minister of Finance, MP Gokaraju Raju asked whether all individual states agreed with the BIPAs, and if not, how the central government intends to fulfil this task. ${ }^{101}$ Regardless of the constitutional law issues this question raises, the Minister responded that in order to ensure effective implementation of BIPAs, a Centre State Investment Agreement (CSIA) would be introduced - this would

\footnotetext{
${ }^{91}$ Ibid.; also interview with O. I. (2015).

${ }^{92}$ ‘ Finance and Commerce \& Industry ministries to discuss draft BIPA model tomorrow’, Economic Times, 13 August 2014 , available at economictimes.indiatimes.com/news/economy/foreign-trade/finance-and-commerce-industry-ministries-to-discussdraft-bipa-model-tomorrow/articleshow/40185478.cms.

${ }^{93}$ Interview with O. I. (2015).

${ }^{94}$ Interview with O. E. (2015); interview with A. Y., high-level official Ministry of Finance (2015). Interview with G. V. (2013).

${ }^{95}$ Interview with O. E. (2015).

${ }^{96}$ Ibid.

${ }^{97}$ See supra note 66.

${ }^{98}$ Interview with R. A. (2015).

${ }^{99}$ Ibid.

${ }^{100}$ Referring to Art. 1(7). The Draft Model BIT included a separate provision to this effect in general exceptions at Art. 16(3).

${ }^{101}$ Minister of Finance by MP Gokaraju Ganga Raju (Lok Sabha), Unstarred Question No. 3302, 5 August 2016.
} 
ensure fulfilment of the obligations of the state governments under the BIPAs'. ${ }^{102}$ Interestingly, the Minister added that 'states which will opt in to sign these Agreements will be seen as more attractive destinations by foreign investors'. ${ }^{103}$

This appears as a curious carrot-and-stick mechanism that could affect the federal power structures of India. ${ }^{104}$ IIAs are clearly the federal government's business. By the use of CSIA, the central government was not directly pressurising individual states to comply and co-operate; it essentially told them that they should sign these agreements in order to be seen as an attractive destination. One can only guess how the responsibility would be distributed under CSIA, but it could have been expected that some trade-offs would take place. Moreover, it must have been clear to the central government that the offered benefit - being 'seen as more attractive destinations by foreign investors' - was illusory. The central government was surely aware of the fact that insofar as IIAs matter to foreign investors' investment decisions at all, the investors know that they apply to the whole country. Whether or not there is a CSIA in place changes nothing for the investor. This way the central government aimed at empowering itself vis-à-vis individual states through responsibilization of the latter while offering an illusion of a bargain. However, the CSIA proposal was reportedly later abandoned by the Ministry, citing 'unforeseen and potentially undesirable consequences'. ${ }^{105}$

In addition to this account, when the Minister of Commerce was asked whether an individual state has ever felt aggrieved or protested to any concessions extended to foreign investors under BITs, the Minister responded: 'There are no such instances'. ${ }^{106}$

One can understand that the central government attempts to aim at full internalization of IIAs such that potential costs of a negative arbitral ruling are borne by the decision-makers authoring the decision. ${ }^{107}$ However, a more plausible explanation may be that, due to the constitutional constraints, the central government is aware of its limited power to do so. ${ }^{108}$ Hence, it is trying to use the illusory argument of CSIA as a carrot to empower itself vis-à-vis individual states. This demonstrates the somewhat unrealistic ambition of the spill-over rationale in that it fails to take account of the existing legal structures and power dynamics at the national level.

\subsubsection{Dispute prevention}

By 2019, there was no centralized practice or procedure to prevent and manage investment disputes. While the official position is that 'all international obligations are taken into account', ${ }^{109}$ there is no specialized institutional procedure or informal practice for reviewing IIAs compliance of various legislative and executive measures. In the words of one respondent, 'there is no conscious design to accommodate it'. ${ }^{110}$

\footnotetext{
${ }^{102}$ Ibid.; also A. Jaitley, 'Budget Speech 2016-2017', 29 February 2016, available at www.indiabudget.gov.in/doc/bspeech/ bs201617.pdf, at 34; Ministry of Finance, DEA, 'Annual Report 2016-2017', available at dea.gov.in/sites/default/files/Annual\% 20Report-2016-17-E.pdf, para. 9(2.2).

${ }^{103}$ Ibid.

${ }^{104}$ See F. Pérez Aznar, 'Federal States and Investment Arbitration', in L. E. Sachs and L. Johnson (eds.), Yearbook on International Investment Law \& Policy 2015-2016 (2017), 326.

${ }^{105}$ Ranjan, supra note 10 , at 302 .

${ }^{106}$ RTI responses from the Ministry of Commerce, compiled as of October 2015 (on file with the authors).

${ }^{107} \mathrm{By}$ full internalization we mean the ideal situation assumed by the supporters of the good governance rationale, i.e., that each actor within the government fully internalizes the knowledge about IIAs, and adjusts the processes and practices accordingly. This point has been raised in the context of the discussion on the IIAs' role in inducing efficient regulation/investment in J. Bonnitcha, L. N. S. Poulsen and M. Waibel, The Political Economy of the Investment Treaty Regime (2017), at 144.

${ }^{108}$ As per RTI responses, the Ministry stated that all IIAs' instruments of ratification are prepared by the L\&T division, and are executed by the President. RTI responses from the Ministry of Commerce, supra note 106.

${ }^{109}$ Ibid.

${ }^{110}$ Interview with A. Y. (2015).
} 
A few recommendations have emerged from the High-Level Committee on Arbitration - such as targeted capacity building, the establishment of an inter-ministerial committee, and creation of 'International Law Advisor' as a specialized agency on investment treaty disputes - but up until 2019, no formal policy or procedure had been adopted. Ranjan criticizes the latter proposal as duplicative and inefficient, for the L\&T, an already existing office designed to provide such services, should be strengthened with representatives of Ministries Finance and Commerce instead. ${ }^{111}$ Minister of Finance Arun Jaitley has also recommended the establishment of an inter-ministerial committee, comprising of the representatives of the Ministries of Finance, Foreign Affairs, and Law, ${ }^{112}$ conspicuously not mentioning the Ministry of Commerce, with which the Finance Ministry has had a long history of competition over the IIAs agenda.

\subsubsection{Internalization through (external) adjustment and (internal) accommodation}

The above analysis allows conceptualizing of the formal-institutional interaction between IIL and governance in more abstract terms. One way of looking at the modifications in the Indian IIAs programme is that it represents a more general approach to the IIL internalization in India, which we call internalization through external adjustment.

Internalization through external adjustment means that the Indian government and public administration's experiences with IIAs are translated mostly into the action regarding external relations, i.e., the Indian treaty programme, instead of into attempts to internalize the experience by accommodating the domestic parameters, policies and processes. The latter would be an instance of what we call internalization through internal accommodation, and a typical example would be a setting up of a review mechanism at the level of the legislative process. ${ }^{113}$ Generally, a state will resort to the combination of the two modes of internalization, while the prevalence of one over the other will be a question of degree. ${ }^{114}$

The Indian reaction was to modify its model BIT, undergo a review of the current stock of IIAs, attempt to directly include provisions in the IIAs to the effect of removing the measures that had been the object of investment claims in the past, and terminate many of its IIAs.

With these concepts, we are not expressing a judgement about the motivations of the relevant actors to pursue this path of internalization. What we want to stress is that the interaction between national governance and an international law regime, such as IIL, generally translates into governance effects going, often simultaneously, in two directions: the international and the national. As internalization through external adjustment requires a significant mobilization among the relevant governance actors (just as internalization through internal accommodation does), it is inevitable that even these acts trigger internal rearrangements, as is demonstrated by the Indian case study. These effects are more properly understood as rearrangement by internalization.

\subsubsection{Rearrangement by internalization}

In the previous section, we argued that a state will usually resort to both internal and external modes of internalization, although in various manifestations and degrees. Regardless of the motivations of the actors that materialized particular policies, external adjustments just as internal accommodations will generally be purposeful acts. Governance actors will resort to them to achieve a particular goal, policy or state of affairs. Now, regardless of how a state resorts to external or internal modes of internalization, we contend that each case of purposeful engagement with an international regime is always accompanied by rearrangements within the national governance

\footnotetext{
${ }^{111}$ Ranjan, supra note 10 , at 307.

${ }^{112}$ Arun Jaitley's Letter to PMO on Vodafone Arbitration dated 26 May 2017, supra note 82.

${ }^{113}$ See van Harten and Scott, supra note 6 . Note that the motivation of these moves may be treaty compliance just as international review avoidance.

${ }^{114}$ Ostřranský and Pérez Aznar, supra note 15.
} 
sphere. These can be materialized in rearrangements of legal competences among various state agencies, creation of new agencies, and, at a more fluid, less material even though no less real and powerful level, in the creation of new narratives, ideational frameworks, and subjectivities.

Thus, while it is useful to map the engagement with IIL through the modes of internalization along the somewhat stylized axis between external and internal to assess the orientation of the state (e.g., more inward-looking versus more globalizing; more rule-making versus more rule-taking; more accommodating versus more experimenting), this perspective is essentially about how a state and its governance actors position the state vis-à-vis international law and a particular international law regime.

The perspective of rearrangement by internalization, on the other hand, is really concerned with what kind of changes happen on the ground, how various power dynamics, structures and hierarchies are (re)negotiated and modified, what values and discourses get traction, and which get suppressed. From this perspective, the international - be it a treaty, stylized international law regime, or arbitration award - may become an actor itself just as it may become a tool in the complex governance reality of a particular state. ${ }^{115}$ From this perspective, the realm of IIL internalization appears as terrain of negotiations, manoeuvres, and struggles between various governance actors. Each human actor negotiating with not only different legal mandates, but also with different interests, resources, constraints, and normative preferences.

This perspective sheds new light, for instance, on the issue of inter-agency tensions described above. Matters of IIL are not viewed simply as 'something to be dealt with', but also as a possibility and opportunity for furthering different interests, agendas, and worldviews. This perspective shifts from assessing the Indian internalization processes through an idealized normative benchmark of 'good governance' to the concrete lived experiences with IIAs. Indian governance actors can be thus viewed not as lacking knowledge, expertise and understanding, as not measuring up to the abstract (Western) global standards. They are instead viewed as actors who may use IIAs in clever, and sometimes even cunning, ${ }^{116}$ ways to manoeuvre through their daily tasks and to achieve their goals or those of the agencies to which they belong. To provide a fuller picture of the lived experiences with IIAs, however, we have to look at the ideological and discursive effects of IIL too.

\subsection{Ideological-discursive effects of IIL in India}

In this section, we assess the government officials and governmental agencies' narratives and discourses about IIL's purposes, roles and effects, and how they are framed by perceptions and contexts, and how they are attended by contradictions. This analysis allows putting into relief the variegated performative functions of IIL's narratives. To be clear, we are not suggesting that IIAs influence perceptions and these perceptions, in turn, influence policy, processes and practices, as if in a linear two-step process. They are better viewed as different facets and dimensions of the interaction between IIAs and the national governance sphere. ${ }^{117}$ We submit that narratives about and normative evaluations of IIAs by various actors discursively frame their range of action, their policies, processes, and practices. But the discursive frameworks are not static and linear, instead, they are contextual and relational. What is more, they are also tinted by the actors' agendas and the issues at hand. Thus, the same actors may deploy different narratives depending on to whom they speak and what they aim to achieve. It is, therefore, more appropriate to conceive of IIAs' discursive and ideological effects manifested in narratives as operating alongside their formal-institutional effects expressed in laws, policies, and processes.

\footnotetext{
${ }^{115}$ Here, we are drawing on Bruno Latour and his Actor-Network-Theory (ANT), which perceives also non-human objects as actors ('actants') as long as they are a source of action. Except for this section, when we refer to actors in this article, we refer to human or institutional actors. See, e.g., B. Latour, Reassembling the Social: An Introduction to Actor-Network-Theory (2005).

${ }^{116}$ Randeria, supra note 14 .

${ }^{117}$ See above Section 2.4.1.
} 


\subsubsection{Official narratives related to IIAs and their purposes: Benign instruments, articles of faith, and unwanted disciplines}

Although the enquiry into the reasons for entering into IIAs was not our primary objective, we by necessity mapped the narratives about the rationales behind the Indian treaty programme. Also, although the Indian IIAs programme began in the early 1990s with the purposes pertaining to that period, ${ }^{118}$ the earlier narratives of what IIAs are for and about have been deployed regularly until the present day in the interactions between various governance actors. This means not only that the narratives themselves can be modified but also that they may be repurposed for different contexts.

The narrative as to the main purpose of IIAs that has emerged over and over again was that of IIAs as important tools for attracting foreign investment and as a tool for investment protection. This narrative could be discerned clearly from the official government press releases accompanying conclusions of various BITs with other countries, ${ }^{119}$ various official documents and presentations, ${ }^{120}$ and responses by ministers to parliamentary questions from members of Rajya Sabha and Lok Sabha (the two chambers of the Indian parliament). ${ }^{121}$ A related claim is that these treaties boost investors' confidence by creating a 'stable legal regime', and hence indirectly contribute to increased investment flows. ${ }^{122}$ Some press releases go even as far as postulating that the agreement 'will increase investment flows' between the contracting states. ${ }^{123}$

These findings confirm the previous studies finding that governments wishing to attract foreign investment are likely to enter into international agreements which they believe will achieve this purpose. ${ }^{124}$ The idea that IIAs may indeed be an article of faith is supported by further data pointing in the same direction. The information received through applications filed under the 2005 Right to Information (RTI) Act confirmed that the government has never conducted an empirical study to prove whether the empirical claim of IIAs attracting foreign investment is valid, and it has never commissioned an external entity to conduct such a study. ${ }^{125}$ This has been confirmed by some respondents. ${ }^{126}$ Nevertheless, we have identified a 2014 econometric study conducted by a DIPP official (expressing personal views) on whether IIAs attract FDI to India, which concluded that in case of India, there is little evidence to support the hypothesis that the BIPA have [sic] improved the FDI inflows either from developing countries or from developed countries ....' ${ }^{127}$

\footnotetext{
${ }^{118}$ See infra note 121.

${ }^{119}$ See, e.g., Press Information Bureau, Government of India, Ministry of Finance, Press Release on BIPAs with Senegal (2005), Saudi Arabia (2006), China (2006), Slovak Republic (2006), Ethiopia (2007), Bangladesh (2008), Myanmar (2008), Iceland (2008), Colombia (2009), on BIPAs with 82 Countries (23 November 2012).

${ }^{120}$ C. Sarkar, Director of National Investment and Infrastructure Fund (DEA), in 'Report: Approaches by Developing Countries to Reforming Investment Rules; South-South Dialogue and Cooperation', South Centre, 17 August 2016, available at www.southcentre.int/wp-content/uploads/2016/09/Ev_160720_UNCTAD-XIV-Investment-Side-event-Report_EN.pdf, at para. 49. A more indirect hint at the role of IIAs in attracting foreign investment may be identified in the Finance Minister's Budget Speeches from the early 1990s: M. Singh, 'Budget 1993-1994 Speech'; 'Budget 1994-1995 Speech', both available at www.indiabudget.gov.in/bspeech.php.

${ }^{121}$ See, e.g., Minister of Finance from MP Chandu Barne Shrirang (Lok Sabha), Unstarred Question No. 365, 11 July 2014 ; Minister of Finance from MP Harish Dwivedi (Lok Sabha), Unstarred Question No. 5174, 24 April 2015.

${ }^{122}$ Minister of Finance from MP Shri Prakash Javadekar (Rajya Sabha), 20 April 2010; Minister of Finance from MP Harish Dwivedi (Lok Sabha), Unstarred Question No. 5174, 24 April 2015.

${ }^{123}$ Press Information Bureau, Government of India, Ministry of Finance, Press Release on the BIPA with the Government of the Union of Myanmar (2008); similarly Press Release on the BIPA with China (2006).

${ }^{124}$ See L. N. S. Poulsen, Bounded Rationality and Economic Diplomacy: The Politics of Investment Treaties in Developing Countries (2015).

${ }^{125}$ RTI responses from the Ministry of Commerce, supra note 106.

${ }^{126}$ Interview with E. N. (2015).

${ }^{127}$ J. Singh, 'Do Bilateral Investment Promotion \& Protection Agreements (BIPAs) attract Foreign Direct Investment (FDI) Inflows into India?', (2014) 3 Interdisciplinary Journal of Management and Behavioural Sciences 8, available at www. eaindustry.nic.in/discussion_papers/BIPA_Research_Study.pdf. Although not based on data collected specifically in relation to India, also DIPP, 'International Investment Agreement between India and Other Countries', supra note 57.
} 
Asking specifically about the early IIAs programme, the officials and other respondents stressed that IIAs were a result of a package of 1991 economic reforms adopted in order to liberalize the Indian economy. ${ }^{128}$ These reforms mirrored policies proposed by the IMF and World Bank, ${ }^{129}$ as well as they were aligned with the global trends in economic policy-making at that time. ${ }^{130}$ This suggests that the Indian government actors were not the source of the main narratives about the purposes. Academic advisors privy to the government economic reform activities of the early 1990s suggested that IIAs were viewed as a 'natural formal aspect of the continuing international economic co-operation with foreign nations, a sort of marriage certificate'. ${ }^{131}$ Other respondents also stressed the IIAs' role as symbolic tokens of economic diplomacy. ${ }^{132}$

The latter view of IIAs as somewhat benign legal tools is in line with the later adopted BIT policy, which argues that, e.g., taxation is (and always has been) outside the purview of IIAs. ${ }^{133}$ If IIAs were boilerplate benign instruments and diplomatic photo-ops, ${ }^{134}$ then the view of IIAs having no or limited legal reach does not seem to be so far-fetched. Moreover, one of the official reasons for the 2013 IIAs programme overhaul was the fact that IIAs' provisions may be subject to broad and ambiguous interpretations and do not adequately reflect the socio-economic realities in India. ${ }^{135}$ The narrative perspective thus allows seeing continuity in the Indian treaty programme rationale, despite the apparent contradictions and changes in its formal legal manifestations. ${ }^{136}$

Although the Indian government may have for long not understood the potential import and consequences of IIAs until it was first hit with a claim, be it due to the lack of domain expertise or the lack of empirical data, we must stress that instances of the official government actors selectively 'feigning ignorance' or downplaying the risks of IIAs occurred long after they had arguably become aware of possible risks (to the extent of being aware of them at the level of the relevant agencies) through first-hand arbitration experience. The instances documented below demonstrate that Indian government actors selectively use arguments based on IIAs depending on who the audience is, and what is the context of the IIA-related issue. The fact that some of the questions require empirical backing, which the government agencies lack by their own admission, does not prevent the forcefulness of their assertions in many, mostly domestic contexts. The instances also show that Indian government actors strive to fit their actions within the prevailing narratives. Instead of creating an entirely new narrative, they deploy the existing one while modifying some elements, and accentuating and silencing others.

The historically pronounced purpose of attracting foreign investment, which is still used by ministries as the main purpose in communications with domestic constituencies, such as the

\footnotetext{
${ }^{128}$ Ministry of Finance, 'Transforming the International Investment Agreement Regime', supra note 39.

${ }^{129}$ Interview with R. N. (2015); interview with A. E. (2016).

${ }^{130}$ See, e.g., S. Pahuja, Decolonising International Law: Development, Economic Growth and the Politics of Universality (2011).

${ }^{131}$ Interview with O. I. (2015). Policymakers sometimes use marriage metaphors when discussing foreign investment policy, see, e.g., A. Roberts, 'Incremental, Systemic and Paradigmatic Reform of Investor-State Arbitration', (2018) 112 AJIL 410, at 417.

${ }^{132}$ Interview with J. H. (2015); interview with E. N. (2015).

${ }^{133}$ See the Model BIT 2015; Office Memorandum, Government of India, Ministry of Finance, DEA, 'Issuing Joint Interpretative Statements for Indian Bilateral Investment Treaties - regarding', 8 February 2016, at 3, para. 5: 'In the treaties which are silent on inclusion or exclusion of taxation measures from the scope, it is implied that such treaties do not apply to any law or measure regarding taxation including measures taken to enforce taxation obligations.'

${ }^{134}$ Interview with J. H. (2015).

${ }^{135}$ Ministry of Finance, 'Transforming the International Investment Agreement Regime', supra note 39, at 6; Sarkar, supra note 120, at para. 49. DIPP, 'International Investment Agreement between India and Other Countries', supra note 57.

${ }^{136}$ The Indian government indeed might not have viewed IIAs as posing any legal risk as corroborated by the fact that prior to 2010, most of the press releases on BIPA conclusions that listed the obligations contained in these BIPAs did not mention FET while it listed other obligations, e.g., Press Information Bureau, Government of India, Ministry of Finance, Press Release on BIPA with Senegal (2005), Saudi Arabia (2006); Iceland (2008); Sudan (2010), despite FET being included in these treaties. C.f. Ranjan, supra note 10, who explains the post-2011 overhaul in terms of discontinuity in the Indian approach to foreign investment in international law.
} 
Parliament, has recently changed in the communications directed to international fora, such as the United Nations Conference on Trade and Development.

In the latter settings, the government seems to hold that the sole purpose is (i) to protect the foreign investor and (ii) to preserve the regulatory powers of the state. ${ }^{137}$ Strikingly, one such document goes as far as stating that IIAs is 'not an instrument for investment promotion as little evidence linking IIAs to increase in FDI'. ${ }^{138}$ This contradictory stance raises many questions. If the promotion of foreign investment is not the main goal, why has the government repeatedly communicated that this is indeed the chief rationale for IIAs domestically? If the goal is solely to protect foreign investors, what is the normative rationale behind giving this protection only to foreigners, if it is not the investment promotion? Why does India have to boost investors' confidence if it is not about investment promotion?

\subsubsection{Contradictions in the official narratives: Contextual repurposing}

While the previous section identified the main official historical rationales behind the Indian IIAs programme, the lack of empirical backing for the main rationales in the hands of the main governance actors, and the evolution of the rationales, this section evaluates specific deployments of these narratives attending to their contexts and contradictions in greater detail.

When one moves away from the official narratives to the actual perceptions of individual governance actors, the image gets more nuanced. Some respondents openly questioned whether IIAs have potential to attract foreign investments. ${ }^{139}$ Some recent events also cast some shadow over the official narrative. The 2013 BIT between the United Arab Emirates and India was concluded during the government moratorium on new IIAs pending the review. Some interview respondents opined that this happened in order to facilitate a specific deal - that is, the Jet-Etihad airlines merger. ${ }^{140}$ This event shows that despite the ostensible IIAs review and moratorium, the government is willing to make exceptions and compromises if it perceives such action as potentially beneficial and expedient. It also shows that the governance actors are willing to make important deviations from its publicly stated positions if it concerns negotiations for foreign capital.

In the context of the central government's accountability for potential domestic repercussions, the central government downplays the possible risks that IIAs may bring along, despite clearly being aware of them. ${ }^{141}$ Despite the fact it has identified the discontent with some of the IIAs regime's features, such as broad arbitral interpretations, as the cause for the overhaul of its treaty programme. ${ }^{142}$

In November 2014 (i.e., in a period after the White Industries award, when the country was facing six new treaty disputes, and the BIT moratorium and review were effective), the Minister of Commerce was asked by an MP in Rajay Sabha, about the specific benefits of BIPAs. The Minister answered:

Year-wise and sector-wise details of the benefits/impact of BIPAs in the last 10 years are not available as these are primarily legal agreements aimed in protecting foreign investments in the post-establishment phase. BIPAs have been instrumental in creating a stable legal regime

\footnotetext{
${ }^{137}$ Sarkar, supra note 120, at para. 52; the Law Commission Report, supra note 61, at para. 1.8; Ministry of Finance, 'Transforming the International Investment Agreement Regime', supra note 39, at 7.

${ }^{138}$ Ministry of Finance, ibid., at 7.

${ }^{139}$ Interview with V. S., high-level official (2014); interview with H. S. (2014); interview with R. A. (2015); interview with E. N. (2015).

${ }^{140}$ Interview with O. I. (2015); interview with E. N. (2015); K. Singh, 'India-UAE Investment Agreement: Why Such Desperate Haste?', Global Research, 6 January 2014, available at www.globalresearch.ca/india-uae-investment-agreementwhy-such-desperate-haste/5363937.

${ }^{141}$ DIPP, 'International Investment Agreement between India and Other Countries', supra note 57.

${ }^{142}$ See supra note 137.
} 
for espousal of claims of foreign investors as per international law. BIPAs have been also critical in generating investor outlook and confidence in the Indian legal and regulatory system. $^{143}$

While admitting that there is no data, the Minister makes unqualified empirical statements in the second part of her response. Presumably, this downplaying of the lack of data is possible, because BIPAs 'are primarily legal agreements'. As if legal instruments do not have any policy and instrumental role and consequences; as if they are indeed benign. In the next sentence, however, she makes precisely such statement about their instrumental role. Even more interestingly, the Minister makes a further extrapolation by linking the fact that IIAs allow foreign investors to bring their claims to investment arbitration under international law (i.e., effectively escaping the domestic legal regime and its remedies) to the presumption that this leads to increased investor confidence in 'Indian legal and regulatory system', the impact of which IIAs aim to minimize.

Another instance of downplaying the IIAs' impact is showed in another answer to a parliamentary question by the Minister of Commerce. In 2013, the Minister was asked 'whether the provisions of these BITs encroach upon the domestic decision-making process in the country'. ${ }^{144}$ The Minister's answer was succinct and unequivocal: 'No, Madam.' ${ }^{145}$ This instance is even more remarkable because, in the same round of questions, the Minister stated that in light of the lost arbitration in White Industries, the government is reviewing the Model BIPA. One wonders what gears the government to review its Model IIA as a result of a lost arbitration, if not potential negative consequences for the state.

The cracks in the official narrative of 'no constraints on national decision-making' become even more apparent if one takes into account the official position that the Ministry of Commerce stated in the response to the request under RTI:

All government decisions are taken taking into account all of India's international law obligations, including those under BIPA.

One could hardly expect a different official position in an RTI, hence it must be taken with a grain of salt. Yet, it shows that the actual uses of and reactions to IIAs are selective. If the above response is the case and IIAs do not 'encroach upon the domestic decision-making process in the country', ${ }^{146}$ why has there been such turmoil in the Indian investment treaty programme in recent years? Looking at the Indian Model BIT, it is unlikely that this is all because of Indian investors abroad.

One may argue that these are one-off cases, in which the requested Minister was that of Commerce, despite the Ministry of Finance being apparently the major player. ${ }^{147}$ However, both Ministries were involved in the review of the country's IIAs stock and argued in the joint documents that IIAs unduly restrict the sovereign power to tax and inadequately take into account Indian socio-economic realities, among other things. ${ }^{148}$ What is more, the Indian executive views

\footnotetext{
${ }^{143}$ Minister of Commerce by MP Shri Palvai Reddy (Rajya Sabha), Unstarred Question No. 324, 26 November 2014.

${ }^{144}$ Minister of Commerce by MP Raghavan Shri M. K. (Lok Sabha), List of Questions for Oral Answers, 6 May 2013.

${ }^{145}$ Ibid.

${ }^{146}$ Ibid.

${ }^{147}$ It was the Ministry of Finance which put the negotiations of new treaties into moratorium in light of the White Industries award; Minister of Finance by MP Ajay Kumar (Lok Sabha), List of Questions for Oral Answers, 22 March 2013. The working group on the IIAs review was chaired by the Secretary of the DEA, Ministry of Finance, with representatives of other Ministries such as Commerce (DIPP), Law and Justice, Coal, Telecommunication, Revenue; Minister of Finance by MP Baijayant Jay Panda (Lok Sabha), List of Questions for Oral Answers, 25 July 2014.

${ }^{148}$ Interview with H. S. (2014); Sarkar, supra note 120, at para. 52; Ministry of Finance, 'Transforming the International Investment Agreement Regime', supra note 39, at 7.
} 
foreign investors as using the IIAs to unjustly put more pressure on the government to negotiate a settlement. ${ }^{149}$

It seems that the main governmental agencies dealing with IIL are aware of the lack of empirical basis for the main rationale for IIAs, as they are aware of the problems which IIAs may cause in terms of investment disputes. Still, they do not shy away from selective blaming of IIAs or downplaying their risks depending on the context. While one can view this state of affairs as a lack of expertise, co-ordination, consistency and organization within public administration, ${ }^{150}$ it is nevertheless at least equally possible to remove the parochial undertones tinted by the ideal(ized) types of 'good (Western) governance' juxtaposed against the 'backwards' or 'underdeveloped' governance and focus instead on the actual use of IIAs narratives as tools for empowerment, struggle and discipline.

\subsubsection{IIAs as empowering and disciplining tools}

After taking stock of the actual deployments of IIAs narratives, we must put in question the conventional frames of IIAs' effects on domestic governance as either good-governance-inducing or regulatory-chill-inducing, by showing their sweeping and indiscriminate nature. Rather, our analysis showed that the landscape of national governance is a variegated site of struggle, manoeuvres and negotiations between different actors who pursue different agendas and interests and are endowed with different resources. From this perspective, IIAs are used by these actors to empower themselves under certain circumstances, but in other circumstances and contexts, IIAs will constrain and limit those same actors.

Over time, we may observe that IIAs-related agenda leads to (i) struggles over the agenda, and (ii) eventual empowerment of certain governance actors. Instead of viewing the instances discussed in the previous sections as examples of ignorance or a lack of expertise, we contend that the contradictory perceptions and uses of IIA-related arguments are tactical and serve as empowering tools. This empowerment is not only horizontal, among different agencies of the executive and the parliament, but also vertical, between the central government and individual states, provinces, municipalities.

Ministers' responses to the parliamentary queries discussed above show that the Ministers frame their responses to shield themselves from a critique from the legislative arm of the state. If successful, such tactical responses may provide them larger room for manoeuvring in the IIAsrelated agenda, and potentially also elsewhere. The same goes for the propositions of various recommendations to ameliorate the extant state of affairs. ${ }^{151}$

While it may be true that officials at the Ministry of Commerce, Finance or elsewhere lack the technical expertise in IIL possessed (and measured) by those who deal with investment disputes as their bread and butter in globalized law hubs, while they may be aware of the lack of empirical evidence to back their claims, they understand well the context within which they have to solve the IIL-related matters. They may, therefore, deploy narratives about IIL and portraits of IIAs which they expect will facilitate achieving their broader goals. In this sense, just as IIAs may constrain them, they may empower them vis-à-vis other governance actors. It may matter little for a ministerial bureaucrat answering to a parliamentarian or communicating with a bureaucrat from a state municipality that their claims about IIL are inaccurate or exaggerated, as long as they help them to deal with the issue at hand. Even better, as long as they facilitate promotion of their

\footnotetext{
${ }^{149}$ Interview with R. A. (2015); interview with E. N. (2015); 'Government Not to Coerce Vodafone, Cairn On Retro Tax Case: Jaitley', The Hindu, 27 March 2016, available at www.thehindu.com/business/Economy/Govt.-not-to-coerce-VodafoneCairn-on-retro-tax-case-Jaitley/article14177944.ece; T. C. A. Sharad Raghavan, 'No question of dropping tax demand against Cairn Energy: CBDT', The Hindu, 21 August 2015, available at www.thehindu.com/business/Industry/no-question-ofdropping-tax-demand-against-cairn-energy-cbdt/article7566465.ece.

${ }^{150}$ Ranjan prefers this explanation, supra note 10 , at 308-9.

${ }^{151}$ See supra note 112 where the Minister of Finance proposes the establishment of an inter-ministerial committee without representatives from the Ministry of Commerce.
} 
institutional or personal competence, agenda, or interest. In other words, governance actors negotiate and manoeuvre the constraints posed by IIAs on a regular basis and in certain contexts they may find IIAs empowering. This perspective allows us to empathetically recognize coherence in the actions that may be criticized as incoherent from the perspective of an idealized type of 'good governance' which is being promoted by the mainstream literature on the spill-over effect of IIAs.

\section{Conclusion}

The argument that IIAs have an effect on governance broadly conceived is hard to deny. Yes, various governance actors do react to their experience with IIAs. Yet, the conventional spill-over argument, as well as its regulatory chill counterpart, are insufficiently nuanced. They assume that that states act to accommodate the requirements of international legal regimes, generally with a view of avoiding liability. And they assume that the states and their agencies will act in a consistent and concerted way, weighing pros and cons, to set up adequate modalities of internalization (rational choice theory). The reality of the public administration in India, and likely in most if not all countries, is far from this theoretical model. It is much messier. At the same time, various governance actors cannot be said to act irrationally when they do not act according to the model of the conventional spill-over argument. Their actions and utterances make sense from a relational and contextual perspective.

The spill-over argument so often voiced in investment law literature is essentially a normative argument based on the premise that states acting to prevent liability under IIAs are necessarily improving the rule of law adherence and good governance. Again, our analysis of the Indian case study demonstrates this argument too is excessively sweeping and lacks subtlety. Our research shows that important actors' actions towards avoiding liability or otherwise do not necessarily lead to internalization through accommodation of IIL obligations, but also to internalization through external adjustment focused on IIL itself. At the same time, this move (just as the accommodation move) is often accompanied by rearrangements within the governance sphere, through which various actors struggle and negotiate for power, using IIAs as a proxy.

From the perspective of ideological and discursive effects, governance actors may use IIAs for their own empowerment even though they may at other times feel constrained by them (IIAs as empowering and disciplining tools). Finally, governance actors act differently depending on the context in which they act, and the addressee of their conduct and communication. IIAs are thus used selectively by government actors to manoeuvre daily tasks and advance different agendas and interests (e.g., the dealing with sub-national governments, dealings among different central government actors, dealing with domestic as opposed to international constituencies). This is in line with previous ethnographical research on the selective uses of international tools by domestic actors. ${ }^{152}$ In the context of IIAs, these treaties seem to operate once as articles of faith and symbolic tokens of economic diplomacy, at other times as convenient tools in internal political struggles within the public administration, yet at other times as unwanted and unfair disciplines and constraints on national decision-making.

IIL scholarship should take seriously the fact that the state is a site of struggle between different actors and fractions with different motivations, agendas, resources, and interests. IIAs create repercussions at the national level which influence governance writ at large. However, to claim that these effects are the rule of law and good governance inducive, notwithstanding the essentially contestable nature of the two terms, is a step too far. Rather, it should be recognized as essentially IIL-legitimizing normative claim. States can certainly do more to centralize competences and strengthen expertise in certain governmental agencies and give them more say in regulatory decision-making, with the view of securing compliance. Whether such centralization is to be welcomed from a normative perspective is a different question. Should governments tilt their

\footnotetext{
${ }^{152}$ Randeria, supra note 14; Dezalay and Garth, supra note 2.
} 
economic and social policies towards compliance with tools of international economic governance by further empowering the already powerful agencies and emboldening the already hegemonic discourses, instead of creating policies and practices responsive to local concerns and global challenges? Whether building more in-house domain expertise is worth developing countries' precious resources is an equally important political question to ask. Comparative assessment of the Indian experience with other countries within our research project to be published in the near future will provide a fuller picture and will answer some of these questions.

Cite this article: Ostřanský J and Pérez Aznar F (2021). Investment treaties and national governance in India: Rearrangements, empowerment, and discipline. Leiden Journal of International Law. https://doi.org/10.1017/ S0922156521000029 